\title{
UJI AKTIVITAS ANTIDIABETES KOMBINASI EKSTRAK ETANOL DAUN ECENG GONDOK (Eichhornia crassipes (Mart.)Solms) DAN DAUN SINTRONG (Crassocephalum crepidioides (Benth.) S. Moore) PADA MENCIT
}

\author{
Andri Priyoherianto*, Panji Ratih Suci, Putri Rizki Cahya Fatimah, \\ Atik Nur Wijayanti \\ Akademi Farmasi Mitra Sehat Mandiri Sidoarjo \\ *: tremenza_andri@yahoo.com
}

\begin{abstract}
ABSTRAK
Diabetes melitus merupakan penyakit gangguan metabolik kronis yang terjadi karena rusaknya sel $\beta$ pankreas ditandai dengan kadar glukosa darah yang melebihi batas normal. Bahan alam yang dapat dimanfaatkan sebagai pengobatan diabetes diantaranya daun eceng gondok dan daun sintrong karena memiliki kandungan antara lain flavonoid, saponin, polifenol, dan tanin yang diduga mempunyai efek antidiabetes. Tujuan dari penelitian ini adalah mengetahui efek terapi kombinasi ekstrak daun eceng gondok dan daun sintrong dalam menurunkan kadar glukosa darah pada hewan coba yang diinduksi aloksan. Serbuk daun eceng gondok dan daun sintrong diekstraksi mengunakan metode maserasi dengan pelarut etanol $70 \%$. Sebanyak 25 ekor mencit dibagi menjadi 5 kelompok, yaitu kontrol negatif CMC-Na 0,5\%, kontrol positif glibenclamide $0,00065 \mathrm{mg} / \mathrm{g} \mathrm{BB}$, ekstrak daun eceng gondok $17,5 \mathrm{mg} / \mathrm{kg} \mathrm{BB}$, ekstrak daun sintrong $10,5 \mathrm{mg} / \mathrm{kg} \mathrm{BB}$ dan kombinasi ekstrak daun eceng gondok $17,5 \mathrm{mg} / \mathrm{kg}$ BB dan daun sintrong 10,5 $\mathrm{mg} / \mathrm{kg}$ BB. Hasil penelitian menunjukkan bahwa ekstrak tunggal daun eceng gondok dan daun sintrong mampu menurunkan kadar gula darah dengan lama pemberian selama 7 hari. Dosis kombinasi efektif menurunkan kadar gula darah dengan dosis kombinasi ekstrak daun eceng gondok $17,5 \mathrm{mg} / \mathrm{kg}$ kombinasi pada pemberian selama 7 hari.
\end{abstract}

Kata Kunci: Diabetes, Mencit, Terapi Kombinasi, Eceng gondok, Sintrong

\section{ABSTRACT}

Diabetes mellitus is a chronic metabolic disorder that occurs due to destruction of pancreatic $\beta$ cells characterized by blood glucose levels that exceed normal limits. The purpose of this study was to determine the therapeutic effect of the combination of water hyacinth leaf extract and Sintrong leaf in reducing blood glucose levels in alloxan-induced experimental animals. Water hyacinth leaf powder and Sintrong leaves were extracted using the maceration method with $70 \%$ ethanol as a solvent. A total of 25 mice were divided into 5 groups, namely negative control CMC-Na 0.5\%, positive control glibenclamide $0.00065 \mathrm{mg} / \mathrm{g} \mathrm{BW}$, water hyacinth leaf extract $17.5 \mathrm{mg} / \mathrm{kg} \mathrm{BW}$, Sintrong leaf extract $10.5 \mathrm{mg} / \mathrm{kg} \mathrm{BW}$ and a combination of water hyacinth leaf extract $17.5 \mathrm{mg} / \mathrm{kg} \mathrm{BW}$ and sintrong leaf 10.5 $\mathrm{mg} / \mathrm{kg} B W$. The results showed that a single extract of water hyacinth and Sintrong leaves was able to reduce blood sugar levels for 7 days. The combination dose was effective in reducing blood sugar levels with a combination dose of $17.5 \mathrm{mg} / \mathrm{kg}$ water hyacinth leaf extract in combination for 7 days. 
Keywords: Diabetes, Mice, Combination Therapy, Water Hyacinth, Sintrong

\section{PENDAHULUAN}

Perkembangan dan perubahan gaya hidup masyarakat di era modern dengan perilaku hidup yang konsumtif menjadikan Indonesia menempati peringkat ke-7 di dunia setelah Negara China, India, Amerika, Brazil, dan Mexico dengan jumlah penyandang diabetes 10 juta pada tahun 2015 . Diabetes melitus (DM) adalah suatu penyakit gangguan metabolik kronis ditandai oleh kadar glukosa darah yang melebihi batas normal. Diabetes Melitus dinilai sebagai salah satu penyakit yang sering ditemukan pada abad ke-21 dengan jumlah penderita yang terus meningkat dari tahun ke tahun $^{(1)}$. Glukosa darah tinggi merupakan faktor risiko tertinggi ketiga untuk penyakit fatal dini setelah tekanan darah tinggi dan penggunaan tembakau. Diperkirakan pada tahun 2040 Indonesi akan menempati peringkat ke-6 di dunia menjadi 16,2 juta jiwa penyandang $\mathrm{DM}^{(2)}$.

Meninjau dari banyaknya efek samping yang dapat ditimbulkan dari penggunaan obat kimia membuat masyarakat lebih memilih menggunakan bahan alam sebagai pengobatan tradisional. Eceng gondok (Eichhornia crassipes (Mart.) Solms) merupakan gulma air mengapung yang memiliki daun tebal, bundar dan lebar. Eceng gondok berkembang biak dengan cepat sehingga dapat merusak biota di sungai ${ }^{(6)}$. Eceng gondok adalah bahan alam yang mengandung banyak senyawa yang bermanfaat sebagai peluruh kencing, bisul, dan $\operatorname{biduran}^{(7)}$.

\section{Sintrong (Crassocephalum} crepidioides (Benth.) S. Moore) merupakan tanaman perdu yang tumbuh di wilayah tropis dan sub tropis. Secara empiris tanaman sintrong dipercaya dapat mengobati sakit kepala, sakit perut, mengobati luka, antiinflamasi, antidiabetes, dan antimalaria. Masyarakat lebih mengenal sintrong sebagai tanaman yang dapat dijadikan lalapan ${ }^{(8)}$.

Berdasarkan penelitian yang dilakukan oleh (Pamungkas, 2015), senyawa flavonoid yang dihasilkan dari ekstrak daun sintrong (Crassocephalum crepidioides (Benth.) S. Moore) memiliki aktivitas untuk menurunkan kadar glukosa 
darah dengan dosis efektif $75 \mathrm{mg} / \mathrm{kg}$ mencapai 148,703 mg/dl. Penelitian yang dilakukan ${ }^{(10)}$. menunjukkan bahwa ekstrak daun eceng gondok (Eichhorn crassipes (Mart.) Solms) pada uji fitokimia etanol memiliki kandungan senyawa flavonoid, fenolik, saponin dan steroid. Tumbuhan yang mengandung senyawa alkaloid, flavonoid, glukosidase dan terpenoid mempunyai aktivitas sebagai antioksidan dan antidiabetes $^{(11)}$. Senyawa yang dihasilkan dari kombinasi ekstrak daun eceng gondok dan daun sintrong diduga memiliki kemampuan untuk menurunkan kadar glukosa darah.

Penelitian ini bertujuan untuk mengetahui ada atau tidaknya pengaruh pemberian kombinasi antara ekstrak daun eceng gondok (Eichhornia crassipes (Mart.) Solms) dan daun sintrong (Crassocephalum crepidioides (Benth.) S. Moore) terhadap penurunan kadar glukosa darah pada mencit (Mus musculus) dengan dosis ekstrak daun eceng gondok $125 \mathrm{mg} / \mathrm{kgBB}^{(12)}$, ekstrak daun sintrong $75 \mathrm{mg} / \mathrm{kgBB}$ dan kombinasi ekstrak daun eceng gondok 125 $\mathrm{mg} / \mathrm{kgBB}$ dan daun sintrong 75 $\mathrm{mg} / \mathrm{kg}$.

\section{METODE PENELITIAN}

Pembuatan Simplisia

Tanaman yang digunakan adalah $3 \mathrm{~kg}$ daun eceng gondok yang diperoleh dari sungai di Dsn. Bantengan, Ds. Barengkrajan, Kec. Krian, Kab. Sidoarjo dan $2 \mathrm{~kg}$ daun sintrong yang diperoleh dari Desa Taman Kayukebek, Tutur, Kab. Pasuruan.

Penelitian ini menggunakan metode maserasi dan pelarut etanol 70\%. Simplisia daun eceng gondok yang sudah halus dimasukkan 586 gram ke dalam wadah dan ditambahkan etanol $70 \%$ sebanyak $1.770 \mathrm{~mL}$. Simplisia daun sintrong yang sudah halus dimasukkan 500 gram ke dalam wadah maserasi dan ditambahkan etanol $70 \%$ sebanyak $1.510 \mathrm{~mL}$. Kedua ekstrak diaduk dan didiamkan selama 3 x 24 jam lalu disaring. Filtrat yang diperoleh dipekatkan dengan Waterbath dengan suhu $60^{\circ} \mathrm{C}$ hingga di dapatkan ekstrak kental selanjutnya dilakukan uji fitokimia dan KLT 


\section{Aktivitas Efek Pemberian \\ Kombinasi Ekstrak Daun Eceng \\ Gondok dan Daun Sintrong}

Ekstrak daun eceng gondok dan daun sintrong dibagi menjadi 3 bagian dosis antara lain pada ekstrak daun eceng gondok $125 \mathrm{mg} / \mathrm{kgBB}$ tikus, daun sintrong $75 \mathrm{mg} / \mathrm{kgBB}$ tikus dan kombinasi ekstrak daun eceng gondok $125 \mathrm{mg} / \mathrm{kgBB}$ tikus dan ekstrak daun sintrong $75 \mathrm{mg} / \mathrm{kgBB}$ tikus. Ekstrak dibuat suspensi dengan $\mathrm{CMC} \mathrm{Na}$ kemudian disondekan kepada mencit secara oral dengan volume $0,5 \mathrm{~mL}$ per mencit. Hal ini dilakukan sesuai dengan kapasitas maksimal lambung mencit yaitu 1,0 mL.

\section{Penyiapan Hewan Percobaan}

Hewan uji yang digunakan sebanyak 25 ekor mencit. kemudian dibagi menjadi 5 kelompok uji, dengan masing-masing kelompok berjumlah 5 ekor, terdiri dari Kelompok kontrol negatif $(\mathrm{KN})$ yang diberikan suspensi CMC 0,5\%, kontrol positif (KP) diberikan glibenclamide $5 \mathrm{mg} / \mathrm{kgBB}$ manusia, dan 3 kelompok lainnya diberi ekstrak daun eceng gondok 125 $\mathrm{mg} / \mathrm{kgBB}$ tikus, daun sintrong 75 $\mathrm{mg} / \mathrm{kgBB}$ tikus dan kombinasi ekstrak daun eceng gondok $125 \mathrm{mg} / \mathrm{kgBB}$ tikus dan ekstrak daun sintrong 75 $\mathrm{mg} / \mathrm{kgBB}$ tikus. Pembuatan menjadi diabetes, mencit yang sudah diadaptasi selama tiga hari dan di puasakan selama 16 jam diinduksi Aloksan dosis $150 \mathrm{mg} / \mathrm{kg}$ BB tikus secara intraperitoneal dengan pemberian 0,1 $\mathrm{mL}$ per mencit. Setelah penginduksian Aloksan selama 1 hari, mencit diberi makan atau minum yang manis untuk merusak pankreas dari mencit. Setiap hari dilakukan pengukuran kadar glukosa mencit, jika sudah mencapai $>200$ mg/dL dikategorikan DM.

Pemberian Perlakuan Terhadap Mencit

1. Hari pertama (T0) dilakukan pengecekan kadar gula darah mencit sebelum penginduksian aloksan dan dipuasakan selama 16 jam sebelum penginduksian.

2. Hari kedua (T1) dilakukan pengecekan kadar gula darah mencit setelah penginduksian aloksan, jika kadar gula darah mencit $>200 \mathrm{mg} / \mathrm{dL}$ dikategorikan DM.

3. Hari ketiga (T2) pemberian ekstrak tunggal, kombinasi ekstrak daun eceng gondok dan daun sintrong, suspensi CMC Na, dan suspensi glibenclamide sesuai dengan dosis 
kelompok yang ditentukan.

Diketahui nilai rendemen daun

Perlakuan diberikan peroral enceng gonfok lebih besar dari pada selama 7 hari dengan pemberian daun sintorong. Setelah mendapatkan dosis satu kali sehari pada pagi ekstrak daun sintrong dan daun enceng hari. Pengukuran kadar gula darah gondok, kemudian dilakukan tahapan dilakukan pada hari ke-1, hari ke3, dan hari ke-7.

\section{HASIL DAN PEMBAHASAN} skrining fitokimia untuk mengetahui kandungan secara kualitatif pada keduanya.

Tabel 1. Hasil perhitungan rendemen

\begin{tabular}{|c|c|c|}
\hline Penetapan & $\begin{array}{c}\text { Enceng } \\
\text { gondok }\end{array}$ & Sintrong \\
\hline Massa simplisia & $586 \mathrm{~g}$ & $500 \mathrm{~g}$ \\
\hline Massa ekstrak & 40,89 & 22,44 \\
\hline Rendemen $(\%)$ & 6,9 & 4,4 \\
\hline
\end{tabular}

Tabel 2. Hasil Skrining Fitokimia Daun Enceng Gondok

\begin{tabular}{|c|c|c|c|}
\hline $\begin{array}{l}\text { Skrining } \\
\text { fitokimia }\end{array}$ & Hasil positif menurut Pustaka & Hasil yang diperoleh & Kesimpulan \\
\hline Alkaloid & $\begin{array}{c}\text { Terbentuk warna merah atau jingga } \\
\text { setelah penambahan reagen Dragendorf. }\end{array}$ & $\begin{array}{l}\text { Terbentuk warna merah bata } \\
\text { dan ada endapan. }\end{array}$ & Negatif \\
\hline Flavonoid & $\begin{array}{c}\text { Terbentuk warna merah bata/ coklat } \\
\text { kehitaman } \\
\text { setelahpenambahan } \mathrm{H}_{2} \mathrm{SO}_{4} \\
\text { (pekat) }\end{array}$ & $\begin{array}{l}\text { Terbentuk warna coklat } \\
\text { kehitaman }\end{array}$ & Positif \\
\hline Saponin & $\begin{array}{l}\text { Terbentuk busa yang stabil. } \\
\text { Tinggi busa dan lama waktu }\end{array}$ & $\begin{array}{c}\text { Terbentuk busa setinggi } \\
\mathrm{cm} \quad \text { pada permukaan } \\
\text { sampel }\end{array}$ & Positif \\
\hline Tanin & $\begin{array}{l}\text { Terbentuk warna coklat kehijauan atau } \\
\text { biru kehitaman }\end{array}$ & $\begin{array}{l}\text { Terbentuk warna coklat } \\
\text { kehijauan }\end{array}$ & Positif \\
\hline Polifenol & $\begin{array}{l}\text { Terbentuk warna biru tua, biru kehitaman } \\
\text { atau hitam kehijauan }\end{array}$ & $\begin{array}{l}\text { Terbentuk warna hitam } \\
\text { kehijauan }\end{array}$ & Positif \\
\hline Bebas Etanol & Tidak Tercium bau ester & Tidak Tercium bau ester & Positif \\
\hline
\end{tabular}

Berdasarkan hasil pengujian pada tabel 2, didapatkan data bahwa uji skrining fitokimia terhadap daun encen gondok dan daun sintrong positif terhadap flavonoid, saponin, tanin, dan polifenol, namun memberikan hasil yang negatif terhadap tanin.

Berdasarkan data hasil uji KLT, dihasilkan nilai Rf sebesar 0,8 pada standar quersetin. Sedangkan pada ekstrak daun enceng gondok 
didapatkan nilai $\mathrm{Rf}$ berturut-turut sebesar 0,85 dan 0,87. Hasil Rf sampel enceng gondok menunjukkan nilai $\mathrm{Rf}$ yan tidak jauh berbeda dengan standar Quersetin, sehingga daun enceng gondok mengandung flavonoid.

Tabel 4. Hasil Uji KLT

\begin{tabular}{|l|c|c|c|}
\hline Sampel & $\begin{array}{l}\text { Warna } \\
\text { noda }\end{array}$ & $\begin{array}{c}\text { Warna } \\
\text { noda } \\
\text { dengan } \\
\text { lampu } \\
\text { UV 366 } \\
\text { nm }\end{array}$ & Nilai Rf \\
\hline \multicolumn{1}{|c|}{ Quersetin } & Kuning & Kuning & 0,8 \\
\hline $\begin{array}{l}\text { Ekstrak } \\
\text { Daun } \\
\begin{array}{l}\text { Eceng } \\
\text { Gondok }\end{array}\end{array}$ & $\begin{array}{c}\text { Kuning } \\
\text { kehijauan }\end{array}$ & Kuning & $\begin{array}{l}\mathrm{Rf}_{1}=0,85 \\
\mathrm{Rf}_{2}=0,87\end{array}$ \\
\hline
\end{tabular}

Persentase Penurunan Kadar Gula

\section{Darah Mencit}

Tabel 5. Presentase penurunan gula darah mencit.

\begin{tabular}{|l|c|c|}
\hline Kelompok & $\begin{array}{l}\text { Rata-Rata } \\
\text { Penurunan } \\
\text { KadarGula } \\
\text { Darah Acak }\end{array}$ & $\begin{array}{l}\text { \% Penurunan } \\
\text { Kadar } \\
\text { Gula Darah } \\
\text { Acak }\end{array}$ \\
\hline $\begin{array}{l}\text { Kontrol (-) } \\
\text { CMC-Na }\end{array}$ & $1 \pm 7,5$ & $1 \%$ \\
\hline $\begin{array}{l}\text { Kontrol (+) } \\
\text { Glibenclamide }\end{array}$ & $42 \pm 5,7$ & $42 \%$ \\
\hline $\begin{array}{l}\text { Ekstrak tunggal } \\
\text { daun eceng } \\
\text { gondok }\end{array}$ & $37,2 \pm 6,1$ & $37,2 \%$ \\
\hline $\begin{array}{l}\text { Ekstrak tunggal } \\
\text { daun sintrong }\end{array}$ & $38,5 \pm 3,7$ & $38,5 \%$ \\
\hline $\begin{array}{l}\text { Ekstrak } \\
\text { Kombinasi } \\
\text { daun eceng } \\
\text { gondok dan } \\
\text { daun sintrong }\end{array}$ & $49,5 \pm 4,5$ & $49,5 \%$ \\
\hline
\end{tabular}

Berdasarkan hasil perhitungan presentase penurunan dapat di ketauhi dosis kombinasi memiliki presentase penurunan kadar gula darah acak lebih tinggi di banding dengan dosis tunggal dan berefek hipoglikemi lebih cepat.

Pengujian aktivitas dalam menurunkan kadar glukosa darah dilakukan dengan menggunakan hewan uji mencit jantan. Pemilihan mencit dengan kelamin jantan dilakukan karena keadaan hormonal mencit jantan lebih stabil dibandingkan betina. Mencit betina akan memiliki kadar glukosa yang lebih tinggi pada saat bunting sehingga berpengaruh terhadap hasil penelitian $^{(12)}$. Mencit yang digunakan berjumlah 25 ekor yang dibagi menjadi lima kelompok. Kelompok kontrol negatif $(\mathrm{KN})$ yang diberikan suspensi CMC-Na 0,5\%, kelompok kontrol positif (KP) diberikan glibenclamide 5 $\mathrm{mg} / \mathrm{Kg}$ BB manusia, dan 3 kelompok lainnya diberi ekstrak daun eceng gondok $125 \mathrm{mg} / \mathrm{kgBB}$ tikus, ekstrak daun sintrong $75 \mathrm{mg} / \mathrm{kgBB}$ tikus dan kombinasi ekstrak daun eceng gondok $125 \mathrm{mg} / \mathrm{kgBB}$ tikus dan ekstrak daun sintrong $75 \mathrm{mg} / \mathrm{kgBB}$ tikus. 
Penginduksian yang digunakan dalam penelitian ini menggunakan aloksan yang bekerja dengan cara dekstruksi produksi insulin pada sel $\beta$ pankreas. Setelah penginduksian aloksan, konsistensi sel-sel $\beta$ pankreas menghilang menyebabkan kerusakan sel sehingga terjadi kondisi hiperglikemia ${ }^{(18)}$. Mencit yang telah dipuasakan selama 16 jam diukur kadar gula darah awal kemudian diinduksi dengan aloksan sebanyak 0,1 mL secara intraperitonial dengan dosis $150 \mathrm{mg} / \mathrm{kgBB}$ tikus. Pengukuran kadar gula darah selanjutnya diukur satu hari sesudah penginduksian. Apabila gula darah masih $<200$ $\mathrm{mg} / \mathrm{dL}$, mencit diberi minuman manis dengan cara disonde sebanyak 0,5 - 1 $\mathrm{mL}$ sesuai kapasitas lambung mencit. Pemberian ekstrak dilakukan setelah kadar gula darah mencit > $200 \mathrm{mg} / \mathrm{dl}$. Pengukuran kadar gula darah dilakukan pada jam ke-6, jam ke-12, dan jam ke-24.

Kadar gula darah pada pemberian glibenclamide mencapai angka normal sampai hari ke-7 yaitu $86,8 \mathrm{mg} / \mathrm{dl}$. Hal ini disebabkan oleh mekanisme kerja dari glibenclamide yang menurunkan glukosa darah dengan meningkatkan kalsium intraseluler dalam sel beta pankreas, sehingga menstimulasi produksi insulin. Meningkatnya rasio insulin, menyebabkan perubahan glukosa menjadi energi bertambah sehingga akan menurunkan kadar gula darah ${ }^{(19)}$. Sedangkan pada kelompok kontrol negatif tidak memberikan pengaruh yang signifikan terhadap kadar gula darah mencit. Hal ini disebabkan karena adanya penggunaan glukosa oleh mencit dalam pembentukan energy dan terjadinya absorbsi glukosa kedalam sel yang di simpan sebagai gula cadangan ${ }^{(18)}$. Kelompok ekstrak tunggal daun eceng gondok memberikan pengaruh terhadap penurunan kadar gula darah mencapai 91,8 mg/dl namun tidak lebih tinggi dari kontrol positif, hal ini dikarenakan adanya kandungan senyawa flavonoid, saponin, tanin, dan polifenol pada daun eceng gondok. Kelompok dengan pemberian dosis tunggal daun sintrong juga memberikan efek penurunan mencapai $88,4 \mathrm{mg} / \mathrm{dl}$ yang hampir sama dengan kontrol positif tetapi masih dibawahnya, hal ini juga disebabkan adanya kandungan 
senyawa flavonoid, saponin, tanin, dan polifenol yang sama seperti ekstrak daun eceng gondok. Sedangkan pada kelompok ekstrak kombinasi memberikan penurunan yang lebih tinggi dibandingkan dengan kelompok tunggal, bahkan melebihi kelompok kontrol positif (glibenclamide) mencapai 35,8 mg/dl menyebabkan hipoglikemia. Hal ini disebabkan kandungan senyawa yang terdapat didalam kedua tanaman bercampur dan memberikan efek yang sinergis sehingga terjadi peningkatan dosis yang menimbulkan efek penurunan lebih tinggi dibandingkan dengan ekstrak tunggal dan bisa menyebabkan hipoglikemi pada dosis kombinasi yang cukup tinggi.

Ekstrak daun eceng gondok dan daun sintrong mempunyai senyawa fitokimia flavonoid, saponin, tanin, dan polifenol dari senyawa-senyawa tersebut terdapat kuersetin yang merupakan senyawa flavonoid. Flavonoid berperan dalam memperbaiki kerusakan jaringan pankreas yang disebabkan oleh alkilasi DNA akibat induksi aloksan yang mampu memperbaiki morfologi pankreas mencit. Flavonoid juga dapat menghambat pengeluaran sitokin, radikal bebas, serta enzim yang berperan dalam peradangan dengan cara degranulasi neutrofil ${ }^{(19)}$. Kandungan senyawa polifenol yang terdapat dalam daun eceng gondok dan daun sintrong juga berperan sebagai antioksidan. Peran polifenol sebagai antioksidan diduga mampu melindungi sel B pangkreas dari efek toksik radikal bebas yang di produksi di bawah kondisi hiperglikemia. Penurunan stress oksidaf dapat mengurangi resistensi insulin dan menghambat kerusakan sel $\beta$-pankreas ${ }^{(12)}$. Saponin dan tanin yang terdapat di ekstrak daun eceng gondok dan daun sintrong juga memiliki peran dalam menurunkan kadar gula darah pada mencit. Saponin bekerja dengan cara menstimulasi keluarnya insulin dari pankreas $^{(19)}$, sedangkan tanin berfungsi sebagai penghambat $\alpha$ glukosidase dan mempunyai aktivitas menghambat hiperglikemi postprandial dengan cara menunda absorbsi glukosa setelah makan ${ }^{(19)}$.

\section{KESIMPULAN}

Berdasarkan hasil dari penelitian yang telah dilakukan, maka dapat diambil kesimpulan sebagai berikut: 
1. Dosis kombinasi ekstrak etanol daun eceng gondok dan daun sintrong bisa menurunkan kadar glukosa darah mencit.

2. Pemberian ekstrak kombinasi lebih cepat memberikan efek penurunan glukosa darah dibandingkan dengan ekstrak tunggal, namun pemberian ekstrak kombinasi juga menyebabkan efek hipoglikemia tinggi.

\section{UCAPAN TERIMAKASIH}

Penulis mengucapkan terima kasih kepada Lembaga Penyedia Dana Internal Akademi Farmasi Mitra Sehat Mandiri Sidoarjo tahun 2019, serta

\section{DAFTAR PUSTAKA}

1) Andarwati, L. dan Khasanah, U., 2011, Pengaruh Senam Kaki Diabetes Terhadap Neuropati Sensorik Pada Kaki Pasien Diabetes Melitus Di Wilayah Puskesmas Tegalrejo. Medika islamika jurnal kedokteran, kesehatan dan keislaman, Vol 6, 16-22.

2) International Diabetes Federation (IDF), 2015, IDF Diabetes Atlas Seventh Edition. International Diabetes Federation (IDF). Diperoleh tanggal 25 November 2019 dari http://www.oedg.at/pdf/1606 Atlas_2 015_UK.pdf.

3) Sharma A., 2012, Transdermal Approach of Antidiabetic Drug Glibenclamide: A Review. International journal of pharmaceutical research and development, Vol. 3(11): 25 - 32.

4) Dipiro J.T., Talbert R.L., Yee G.C., Matzke G.R., Wells B.G., dan Posey L.M., 2015, Pharmacoteraphy A Patophysiologic Approach, 9th edition. Mc Graw Hill, New York.

5) Ditjen PEN, 2014, Obat Herbal Tradisional, Kementrian Perdagangan Republik Indonesia.

6) Rorong JA, Suryanto E., 2010, Analisis Fitokimia Eceng Gondok (Eichornia crassipes (Mart.) Solms) dan Efeknya Sebagai Agen Photoreduksi $\mathrm{Fe}^{3+}$. Chemistry Progress. Vol 3(1):33-41.

7) Istiandar W. 2011. Kumpulan 1001 Ramuan Obat Tradisional Indonesia.Mojokerto. Cetakan pertama: Pabrik Jamu Dayang Sumbi.

8) Sari, 2016, Uji Aktivitas Antibakteri Ekstrak Etanol Dan Fraksi Daun Sintrong Terhadap Bakteri Escherichia Coli dan Staphylococcus Aureus. Universitas Sumatera Utara : (USU-IR).

9) Hasanah M., Muhamad R.A.P., Kiki A., 2016, Potensi Antioksidan Ekstrak Dan Fraksi Daun Eceng Gondok (Eichornia Crassipes (Mart.) Solms) Yang Berasal Dari Salah Satu Rawa Di Palembang, Indonesia.

10) Yulianti, 2014, Uji Aktivitas Penghambat Enzim Alfa Glukosidase Ekstrak Metanol 80\% Daun Eceng Gondok (Eichornia crassipes (Mart.) Solms) secara in vitro [Skripsi], Jakarta, UNIV 17 Agustus 19.

11) Mokoagouw M., Jeane M., Wilmar., Royke RP., Selvana S., Tulandi, 2019, Uji Efektivitas Daun Eceng Gondok (Eichornia crassipes (Mart.) Solms) pada Tikus Putih (Rattus norvegicus) sebagai Diuretik. Journal 
BiofarmasetikaTropis, Vol 2(2) :55-60.

12) Alamsyah HK., Ita W., Agus S, 2014, Aktivitas Antibakteri Ekstrak Rumput Laut (Sargssum Cinereum (J.G.Agardh)) dari Perairan Pulau Panjang Jepara Terhadap Bakteri Escherichia coli dan Staphyloccocus epidermis.Semarang. Journal of Marine Research, Vol 3(2), 69-78.

13) Asih, I.A.R. Astuti, 2009, Isolasi dan Identifikasi Senyawa Isoflavon Dari Kacang Kedelai (Glycin max). Jurnal. Bukit Jimboran, FMIPA, Universitas Udayana. Hal: 35.

14) Simaremare ES. 2014. Skrining Fitokimia Ekstrak Etanol Daun Gatal (Laportea decumana (Roxb.) Wedd). PHARMACY 11(01):98107.

15) Irdalisa., Safrida., Khairil., Abdullah., Mustafa, S., 2015, Profil Kadar Glukosa Darah Pada Mencit Setelah Penyuntikan Aloksan Sebagai Hewan Model
Hiperglikemia. Banda Aceh. Jurnal EduBio Tropika, Vol 3(1) : 1-50.

16) Decroli Eva, 2019, Diabetes Melitus Tipe 2, Padang: Edisi Pertama.

17) Rizky karotinga. 2013. Makalah kimia bahan alam " isolasi dan identifikasi senyawa flavonoid". Diakses tanggal 25 November 2019 dari http://Rizkaritonga.04/bab-ipendahuluan-senyawa-metabolit.

18) Sediarso, Hadi S., Nurul A. 2013. Efek Antidiabetes dan Identifikasi Senyawa Dominan Fraksi Kloroform Herba Ciplukan (Physalis Angulata L.). FMIPA Universitas Muhammadiyah Prof. Dr. Hamka, Jakarta. Majalah Ilmu Kefarmasian. Vol. 8, 1-56.

19) Eryuda F., Tri U.S. 2016. Ekstrak Daun Kluwih (Artocarpus camansi) Dalam Menurunkan Kadar Glukosa Darah Pada Penderita Diabetes Melitus. Majority Journal, volume 5, halaman 71-72. 